\title{
The United States in Latin America: the overstated decline of a superpower
}

Article

Accepted Version

Long, T. (2016) The United States in Latin America: the overstated decline of a superpower. The Latin Americanist, 60 (4). pp. 497-524. ISSN 1557-203X doi:

https://doi.org/10.1111/tla.12094 Available at https://centaur.reading.ac.uk/67969/

It is advisable to refer to the publisher's version if you intend to cite from the work. See Guidance on citing.

To link to this article DOI: http://dx.doi.org/10.1111/tla.12094

Publisher: Wiley Online

All outputs in CentAUR are protected by Intellectual Property Rights law, including copyright law. Copyright and IPR is retained by the creators or other copyright holders. Terms and conditions for use of this material are defined in the End User Agreement.

\section{www.reading.ac.uk/centaur}

\section{CentAUR}

Central Archive at the University of Reading

Reading's research outputs online 


\section{The United States and Latin America}

\section{The overstated decline of a superpower}

"Well into the 1990s Washington still exerted significant influence across the region. By contrast, today it exercises less regional influence, and conversely, Latin American states display greater autonomy than at any time in the last one hundred years. ... By the end of the $21^{\text {st }}$ century's first decade, Latin American governments had stopped paying much attention to the United States."

--Mark Eric Williams, $2015^{1}$

"[T]he United States and Canada are being virtually expelled from the hemisphere."

--Noam Chomsky, 2013²

\section{Introduction}

After emerging from the Cold War as the uncontested, unipolar power, ${ }^{3}$ the United States now sees itself beset by challengers. Its own power has been undermined by political paralysis, economic weakness, imperial overstretch, and costly bad decisions. In some cases, these bad decisions have spurred embryonic counterbalancing coalitions. ${ }^{4}$ The U.S. inability to respond has, meanwhile, allowed a resurgent Russia and growing China to enhance their positions at the United States' expense. This adds up to a new conventional wisdom: the United States is a power in decline. ${ }^{5}$ For many analysts over the past decade, China is the power of tomorrow. ${ }^{6}$ For others, such as Charles Kupchan, we have entered No One's World. ${ }^{7}$ By 2010, even the U.S. intelligence establishment had seemingly accepted the fact that U.S. unipolarity was nearing an end. Just 15 years hence, its Global Trends report proclaimed, the world would be an "almost unrecognizable," "global multipolar" system, characterized by the "transfer of global wealth and economic power." ${ }^{\prime 8}$ The message: goodbye "indispensable nation."

\footnotetext{
${ }^{1}$ Mark Eric Williams, "The United States and Latin America," in Routledge Handbook of Latin America in the World, ed. Jorge I. Domínguez and Ana Covarrubias Velasco (New York: Routledge, 2015), p. 199.

${ }^{2}$ Noam Chomsky, "America's imperial power is showing real signs of decline," AlterNet, August 2, 2013. Online: http://www.alternet.org/world/chomsky-americas-imperial-power-showing-real-signs-decline

${ }^{3}$ Michael Mastanduno, "Preserving the Unipolar Moment: Realist Theories and US Grand Strategy after the Cold War," International Security 21, no. 4 (1997).

${ }^{4}$ Robert A. Pape, "Soft Balancing against the United States," International Security 30, no. 1 (2005).

${ }^{5}$ For similar conclusions from two very different perspectives, see Chris Chase-Dunn et al., "Last of the Hegemons: US Decline and Global Governance," International Review of Modern Sociology (2011), Christopher Layne, "The Waning of US Hegemony-Myth or Reality? A Review Essay," International Security 34, no. 1 (2009).

${ }^{6}$ Randall L Schweller and Xiaoyu Pu, "After Unipolarity: China's Visions of International Order in an Era of US Decline," International Security 36, no. 1 (2011). For a summary of these arguments, and a counterpoint, see Joshua R Itzkowitz Shifrinson and Michael Beckley, "Debating China's Rise and US Decline," (2012). ${ }^{7}$ Charles A Kupchan, No One's World: The West, the Rising Rest, and the Coming Global Turn (Oxford University Press, 2012).

${ }^{8}$ National Intelligence Council, Global Trends 2025: a Transformed World (National Intelligence Council, 2008), p. vi.
} 
This argument has been frequently extended to the United States' position in the Western Hemisphere, where its power was long unrivalled-or so many analysts still claim. An early period of consensus has collapsed: "The 2000s, in contrast, witnessed strong divergences between Latin American countries and the United States. The United States was no longer capable-perhaps unwilling-to shape and influence the regional system." ${ }^{10}$ The United States faces new rivalries for Latin American loyalties. "Iran, Russia, and China have all significantly increased their economic and political footprints in the region," Russell Crandall avers. ${ }^{11}$ That leaders from the United States' supposed "backyard" now spearhead projects to counter U.S. influence seems like the coup de grace for a creaking heavyweight. The "pink tide" that took power starting with Venezuela's Hugo Chavez in the late 1990s both took advantage of and contributed to "the waning influence of the United States." ${ }^{12}$ Latin America now had the means, the motivation, and the leadership to increase its distance from Washington. Plus, it could now get a little help from rising friends. In early 2015, Argentine historian Leandro Morgenfeld cited ALBA, CELAC, and UNASUR to argue that, "During the 21st century, Latin America has advanced as never before in a process of regional integration outside of Washington's orbit." ${ }^{13}$ The United States was shunned from within and challenged from without. The Americas, it seemed, were experiencing a Copernican revolution.

This decline is not what it seems. Too often, U.S. decline is assumed as a precondition for the study of other phenomena, such as the rise of the Latin American left or the role of China. Other arguments build on selective readings and oversimplifications of U.S. influence during the past. By foregrounding these assumptions, this article questions the idea that U.S. power in the hemisphere entered a phase of new, steep decline during the mid-2000s. While the hemisphere has experienced important changes, many of these precede the current declinist debate. Claims of declining U.S. power (or influence) in Latin America and the Caribbean have suffered from a lack of conceptual clarity. This paper places the debate about the U.S. position in the hemisphere in the context of broader discussions about power in International Relations.

The remainder of the essay will be divided in several sections. First, it will survey the recent debate on the state of U.S. power in the hemisphere, with particularly attention to the concepts of power that are implied in these analyses. Secondly, it will briefly explore divergent approaches to power prevalent in International Relations, where the concept is both central and contested. Instead of advocating one particular approach to power, the article will employ a range of concepts, developing indicators for each. What do these indicators tell us about U.S. power, as well as that of extra-hemispheric powers, in the region? The conclusions argue that U.S. decline has too often been assumed instead of

\footnotetext{
${ }^{9}$ For a summary of the evolution of this perspective, along with some prescient doubts about it, see Michael Cox, "Power Shifts, Economic Change and the Decline of the West?," International Relations 26, no. 4 (2012).

${ }_{10}$ Jorge I. Domínguez and Ana Covarrubias Velasco, eds., Routledge Handbook of Latin America in the World (New York: Routledge, 2015), p. 9.

${ }^{11}$ Russell Crandall, "The Post-American Hemisphere," Foreign Affairs 90, no. 3 (2011).

12 Maxwell A Cameron and Eric Hershberg, Latin America's Left Turns: Politics, Policies, and Trajectories of Change (Boulder, Colo.: Lynne Rienner, 2010), p. 18.

${ }^{13}$ Leandro Morgenfeld, "Eeuu-Cuba: Un Giro Histórico Que Impacta sobre América Latina y el Caribe," Crítica y Emancipación 6, no. 12 (2015): p. 114.
} 
demonstrated, that when evidence has been provided it has often been anecdotal, and that this evidence actually demonstrates significant continuities. U.S. decline, both relative to extra-hemispheric powers and in regards to states within the region has been overstated because of a tendency to exaggerate U.S. power in the past and an underestimation of the continued depth of U.S. military, economic, structural, and relational power in the region. The United States retains substantial power in the hemisphere. That said, U.S. fiat is hardly law across the hemisphere, as Secretary of State Richard Olney arrogated. The limitations on U.S. power, however, are less a product of the growing influence of external actors and more the result of changes within Latin America and in the conduct of international politics more generally.

\section{The declinists' debate}

Despite first appearances, the debate over declining U.S. power is not a debate over disparate answers to the same question. Instead, there are several different questions at work, and these often draw on divergent implicit concepts of power: relative versus absolute; military versus economic; soft versus hard; material versus ideational; relational versus structural; or in relation to extra-hemispheric rivals versus hemispheric autonomy. These aspects of power are sometimes interrelated. However, even then, these concepts can give us very different answers to the seemingly simply query of whether U.S. power is waxing or waning. Setting aside the disagreement over the United States' global stature, this section surveys the literature on the U.S. role in the Western Hemisphere. One interesting facet of the declinist debate is that is seems to have produced rare agreement from a range of U.S. and Latin American scholars who are usually found in opposite corners. ${ }^{14} \mathrm{~A}$ certain trend is prevalent in these studies. Early entries, often responding to the unpopularity of the George W. Bush administration on the Iraq War in Latin America, initially cast the decline in U.S. influence as the result of bad decisions and/or U.S. distraction or "neglect." ${ }^{15}$ Spurred by the financial crisis and the deceptively rapid recoveries of many Latin American economies, the emphasis gradually changed to a decline in U.S. power.

The "inattention" narrative focused on malleable policy agendas and echoed earlier descriptions of cyclical U.S. attention to the hemisphere. ${ }^{16}$ Advanced by influential policy analysts including Peter Hakim, this position was repeated by the commander of U.S. Southern Command in 2010: "many credible observers continue to counsel that the United States must pay more attention to this vitally

\footnotetext{
${ }^{14}$ Echoing earlier reviews, Russell Crandall divides the literature on U.S.-Latin American relations between "antiimperialists" and U.S. "establishment" scholars. Russell Crandall, The United States and Latin America after the Cold War (New York: Cambridge University Press, 2008), pp. 4-8. See also the much earlier, Robert A. Pastor, "Review: Explaining U.S. Policy toward the Caribbean Basin: Fixed and Emerging Images," World Politics 38, no. 3 (1986), Abraham F. Lowenthal, "United States Policy toward Latin America: "Liberal," "Radical," and "Bureaucratic" Perspectives," Latin American Research Review 8, no. 3 (1973). Modifying these categories somewhat, Long adds an emerging "internationalist turn" that seeks to incorporate Latin American perspectives and sources. The debate on U.S. decline, however, has largely omitted these, making Crandall's original dichotomy rather apt. Tom Long, Latin America Confronts the United States: Asymmetry and Influence (Cambridge University Press, 2015). ${ }^{15}$ An early establishment piece along these lines is Peter Hakim, "Is Washington Losing Latin America?," Foreign Affairs 85, no. 1 (2006).

${ }^{16}$ The most prominent description is Robert A. Pastor, Exiting the Whirlpool : U.S. Foreign Policy toward Latin America and the Caribbean (Boulder, Colo.: Westview Press, 2001).
} 
important part of the world-and I could not agree more."17 However, the focus on inattention was not limited to U.S. policy and military thinkers. Marco A. Gandásegui Jr., a scholar critical of U.S. policies, wrote in 2011 that, "in the first two years of the Obama administration, Latin America has practically been erased from the map in the White House," though Gandásegui later adds that "As far as Obama is concerned, Latin America has just five countries," ${ }^{18}$ which must produce a very strange, practically erased map. R. Guy Emerson rejects the "inattention" explanation to argue that Washington's expansion of the "war on terror" paradigm provoked the divide with Latin America, particularly its expansion to Colombia in collaboration with former Colombian President Álvaro Uribe. Emerson notes that U.S. material preponderance overstates U.S. abilities to determine outcomes in the hemisphere, and that "recognition of state agency" is needed. ${ }^{19}$

More recent explanations have shifted beyond inattention to the question of power. A number of "antiimperialist" scholars have placed the primary sources of decline within the United States itself. Greg Grandin has gone so far as to refer to U.S. policy, driven by narrow domestic interest groups, as the "empire's senescence." ${ }^{20}$ Often, the slow Western recovery from the 2008 crisis is offered as proof of this global decline. Often, the decline in U.S. influence is scene-setting for the exploration of emerging regional or national political projects. ${ }^{21}$ Legler notes that "U.S. influence in Latin America also has decreased substantially in recent years," given Latin American "post-hegemonic" regional projects, the rise of the left, and the death of the FTAA. ${ }^{22}$ Gardini examines whether Brazil will step in to fill "the vacuum left by US retrenchment." ${ }^{23}$ Latin American efforts to promote counterhegemonic unity deserve much credit: "all of these processes threaten the 'unipolar' hegemony of the world's superpower and make possible, although by no means guarantee, what Lenin called a 'break in the weak links of the chain of imperialist domination,'" Cuban sociologist Darío Salazar wrote. Alternative regional arrangements have improved odds of success in an international context where the "unipolarity resulting from the end of the Cold War will be increasingly substituted by a multipolarity that in turn

\footnotetext{
17 James Stavridis, Partnership for the Americas : Western Hemisphere Strategy and U.S. Southern Command (Washington, D.C.: National Defense University Press, 2010), p. 50.

${ }_{18}$ Marco A. Gandásegui, "President Obama, the Crisis, and Latin America," Latin American Perspectives 38, no. 4 (2011): p. 110, 118. He does not clearly state which five, and in the ensuing two paragraphs mentions Venezuela, Colombia, Mexico, Costa Rica, Panama, Trinidad and Tobago, Honduras, and Ecuador.

${ }^{19}$ R. Guy Emerson, "Radical Neglect? The "War on Terror" and Latin America," Latin American Politics and Society 52, no. 1 (2010).

${ }^{20}$ Grandin, Greg. 2010. "Empire's Senescence: U.S. Policy in Latin America." New Labor Forum 19 (1): 15-23,126

${ }^{21}$ The introduction to one recent volume notes "the many crises of neoliberalism and the collapse of US-led hemispheric leadership" as the context in which new projects are being formed. Pía Riggirozzi and Diana Tussie, The Rise of Post-Hegemonic Regionalism: The Case of Latin America, vol. 4 (Springer Science \& Business Media, 2012), p. 3.

22 Thomas Legler, "Post-Hegemonic Regionalism and Sovereignty in Latin America: Optimists, Skeptics, and an Emerging Research Agenda," Contexto Internacional 35, no. 2 (2013): p. 333.

${ }^{23}$ Gian Luca Gardini, "Brazil: What Rise of What Power?," Bulletin of Latin American Research 35, no. 1 (2016).
} 
opens up new opportunities for popular change in the Americas. ${ }^{24}$ "The United States has already lost its trade presence in the Southern Cone," Gandásegui claims. ${ }^{25}$

While the anti-imperialists may be more gleeful in their assessment of U.S. decline, they are hardly alone. Russell Crandall wrote, "Across the region in recent years, the United States has seen its influence decline." One of the most influential of a younger generation of "establishment" scholars, Crandall blamed this loss of influence on U.S. mistakes, but also new regional organizations and Latin America's quest for "friends and opportunities outside of Washington's orbit." ${ }^{26}$ Latin American economic growth, led by Brazil, and democratic consolidation have bred new diplomatic self-confidence. Crandall's conclusions are worth quoting at length, given his paradigmatic mixture of overstating past U.S. power and projecting "inevitable" decline in future influence:

“Nonetheless, Latin America's emerging democratic consensus seems inevitable, and as its strategic posture finally matures, the region will be more directly responsible for its own successes and failures. Long Latin America's master, the United States must adapt to the new realities of this post-hegemonic era, lest it see its influence diminish even further. It must demonstrate an ability to quietly engage and lead when appropriate--an approach that will allow Washington to remain actively involved in the region's affairs without acting as though it is trying to maintain its legacy of hegemony. Given how accustomed the United States is to dominating the region, this project will be harder than it sounds." ${ }^{27}$

Crandall's assumptions of U.S. decline in the hemisphere are shared by influential establishment authors. While acknowledging U.S. missteps and abuses of power, Sabatini argues that U.S. leadership has brought important economic and political benefits. But by 2009, "the power equation within the hemisphere had shifted" away from the century-long situation in which "the United States enjoyed unrivalled power in the hemisphere." 28 Sabatini critiques other declinist accounts for confusing a loss of power with "anti-Americanism," though he risks overstating the high points of U.S. power during "the near 170 years of U.S. hegemony or the halcyon days after the Cold War." Historically, U.S. power in the hemisphere has been "military, economic and financial, and diplomatic, and to those should be added the admittedly vague factors of moral and aspirational power." Military power is much less relevant; economic power is challenged by Brazil's growth and China's role, Sabatini argues.

Sabatini is measured: "long-term" U.S. power remains, seen in economic ties and diplomatic alignments that survive specific policy disagreements. Much ballyhooed Latin American alternative institutional arrangements like PetroCaribe were already weakening by 2013, while UNASUR and CELAC "remain for now just a roving series of presidential summits." ${ }^{29}$ U.S. normative and aspirational power (similar to

\footnotetext{
${ }^{24}$ Luis Suárez Salazar, "The Current Crisis of US Domination over the Americas," Critical Sociology 38, no. 2 (2012): pp. 186, 191.

${ }^{25}$ Gandásegui, "President Obama, the Crisis, and Latin America," p. 120.

${ }^{26}$ Crandall, "The Post-American Hemisphere."

27 lbid.

${ }^{28}$ Christopher Sabatini, "Will Latin America Miss US Hegemony?," Journal of International Affairs 66, no. 2 (2013): pp. 7-8.
}

${ }^{29}$ Ibid., p. 11. 
Nye's soft power) run deeper still. Sabatini concludes by agreeing that "U.S. power has indeed declined," though without having given clear indicators of how much.

Mark Eric Williams is more optimistic about the future of the Western Hemisphere with a shrinking United States and growing Latin America: "increasingly confident Latin American states have moved on" from the U.S.-led order. ${ }^{30}$ Williams sets out to "[explain] the U.S. decline," focusing on three factors: domestic political changes in the region, global economic shifts, and "regional reactions to U.S. foreign policy." Williams largely focuses on opposition in the region to the pre-emptive, unilateral, and militarized foreign policies of George W. Bush, along with ham-handed opposition to elected leftist leaders in the region. A region with bolder leaders, deeper reserves, and outside economic options no longer had to accept these policies, he argues. Williams offers "Multiple indices [of] the remarkable decline of U.S. regional influence," though he provides only examples of when the U.S. did not get its way and not indices (discussed on page25).

Other scholars have focused more directly on the importance of rising extra-hemispheric actors, harkening to the Monroe Doctrine. According to Roett and Paz, "China's expanding diplomatic and economic ties with the region, the backyard of the United States, have awakened new concerns in U.S. policy circles." ${ }^{11}$ However, they note, U.S.-Chinese ties are likely to retain priority over either's links with Latin America. Roett and Paz see the decline of U.S. influence as the result of both policy failures (on trade and migration, for example), the emergence of an "anti-American, antimarket, anti-FTAA, antiDoha, and antiimperialist" left in Latin America, and the rise of China. The China option gives what the authors deride as the "wrong left" a lifeline as an alternative market, source of investment and finance, and source of South-South diplomatic cooperation to reduce U.S. influence. ${ }^{32}$

Strategic analysts have painted a grim picture of U.S. capabilities in the region. In an exercise of hyperbolic projectionism, De Santibañes argued in 2009 that the U.S. "has not paid enough attention to what is happening in the Western Hemisphere" even as the growing Chinese presence is "seeding the field for a series of political alliances that, once unleashed, would endanger American security." The Southern Cone, he implies, may "join China's sphere of influence." ${ }^{33}$ Given its capabilities, China has rightly received the greatest attention. However, fearful declinists also invoke the specter of other rivals as threats to fill the Latin American void and therefore threaten the United States. These include a Russians, ${ }^{34}$ "nefarious" Iranian mullahs, ${ }^{35}$ and exogenous non-state actors. Sometimes, this void is

\footnotetext{
30 Williams, "The United States and Latin America," p. 204.

${ }^{31}$ Riordan Roett and Guadalupe Paz, China's Expansion into the Western Hemisphere: Implications for Latin America and the United States (Washington: Brookings Institution, 2008), p. 1.

32 Ibid., pp. 13-16.

${ }^{33}$ Francisco De Santibañes, "An End to U.S. Hegemony? The Strategic Implications of China's Growing Presence in Latin America," Comparative strategy 28, no. 1.

${ }^{34}$ With more than a hint of threat inflation, Farah and Reyes argue: "Russian officials have been brazen about their desire to undermine and confront the United States in the Western Hemisphere, its main sphere of influence, to counter what Russia perceives as U.S. interference in Russia's border territories. In the current Latin American context Russia has made greater progress toward their goals than is usually acknowledged." Douglas Farah and Liana Eustacia Reyes, "Russia in Latin America: A Strategic Analysis," Prism : a Journal of the Center for Complex Operations 5, no. 4 (2015).
} 
invoked explicitly: “The Barack Obama administration's de-prioritization of Latin America has created a political vacuum in the post-American hegemony era which Russia is happy to fill and Latin American leaders welcome." ${ }^{36}$ Not only do Latin American states welcome U.S. adversaries with open arms, but the weakness of those same states offers space for extra-hemispheric, non-state actors who would also launch attacks from Latin America. Admiral Kurt W. Tidd, Commander of the U.S. Southern Command, stressed the risk that endogenous Latin American criminal networks would make common cause with "Sunni or Shi'a extremists" and "violent extremist organizations" linked to the Syrian conflict. Though Tidd admitted a lack of evidence or intelligence to support these warnings, he still dedicated a substantial portion of his March 10, 2016 "posture statement" to emphasizing the threat. ${ }^{37}$ While Tidd has gone to great lengths to revive the fabled "El Qaeda" connection, Southcom has made a point of stressing these ties for more than a decade.

There are reasons to doubt the importance of some of the states cited as rivals to the United States in the hemisphere. Iran's real military, commercial, and financial presence has been almost null. Russia's role has been symbolic or focused on arm sales, while it deals largely with stoking fires in its "near abroad" in Ukraine and Syria. Finally, despite nearly fifteen years of warnings, the U.S. Southern Command is unable to marshal evidence of significant connections between international Islamist extremists and Latin American transnational organized crime. Of the cited extra-hemispheric powers, only China has a substantive role, though analysts from across the spectrum stress its commercial motivations (sometimes accompanied by an ominous "for now").

\section{What we talk about when we talk about power}

One reason for the imprecise debate about the direction and future of U.S. power in Latin America is that though central, the nature of power in International Relations more broadly is hotly contested. Simply put, there is no consensus over how to understand power. Even major theoretical paradigms harbor internal disagreements about the nature of power and how to operationalize it. While realism has long set the terms of the power debate, ${ }^{38}$ even that paradigm disagrees on whether power should be treated as material capabilities or as relational. ${ }^{39}$ Very broadly, the most common approaches to power in IR can be divided into potential and kinetic forms of power. Potential power refers to resources - traditionally military capabilities or population and wealth that can be converted to military capabilities. Kinetic power emerges from Robert Dahl's classic formulation that power is relational. " $A$ has power over $B$ to the extent he can get $B$ to do something that B would not otherwise do." ${ }^{40}$ The

\footnotetext{
35 U.S. Admiral Kurt W. Tidd used this label in recent testimony about Iran's activities in the Western Hemisphere. ${ }^{36}$ Jose de Arimateia da Cruz, "From Ideology to Geopolitics: Russian Interests in Latin America," Current Politics and Economics of Russia, Eastern and Central Europe 30, no. 1-2 (2015): p. 183.

${ }^{37}$ Senate Armed Services Committee, Posture Statement of Admiral Kurt W. Tidd, Commander United States Southern Command, 114th, March 102016.

${ }^{38}$ Felix Berenskoetter, "Thinking About Power," in Power in World Politics, ed. Felix Berenskoetter and M.J. Williams (New York: Routledge, 2007).

39 This is not simply a question of "new" versus "old" realism, either. While many realists have adopted versions of Robert Dahl's famous approach to power, others like John Mearsheimer argue for a focus on resources.

${ }^{40}$ Robert A Dahl, "The Concept of Power," Behavioral science 2, no. 3 (1957): pp. 202-203.
} 
potential/kinetic dichotomy is hardly exhaustive. Critics of realist and liberal concepts of power have noted that the effects of power are not always visible; power can be reflected in agendas and "nondecisions, ${ }^{141}$ in how weaker actors define their own interests, ${ }^{42}$ or in structures that shape frameworks and guide processes. ${ }^{43}$ These scholars highlight questions of whether power must be intentional or whether it must be damaging to the influenced party to be considered power at all. On the whole, these critiques serve as a warning against overstating the decline of leading powers, given the weight of less observable effect of ensconced institutions, norms, and structures. In an influential article, Barnett and Duvall argue that IR needs to incorporate multiple conceptions of power, treated as a product of social relations. Power can be embedded in discourses, identities, or institutions constructed outside the control of any given actor. Barnett and Duvall argue: "Analysis of power in international relations, then, must include a consideration of how social structures and processes generate differential social capacities for actors to define and pursue their interests and ideals." ${ }^{\prime 4}$

Comprehensively addressing these fundamental, and often ontological, debates about the nature of power is far beyond the purpose of this article. Instead, we draw on various concepts of power as lenses to better view the U.S. position. This following section will examine a few of the relevant approaches to power in IR, asking whether that measure of U.S. power in Latin America has declined. It is worth noting that Susan Strange described her concept of structural power by pointing to "the persistent myth of lost hegemony" in 1987-seeking to upend the myth of "America's lost hegemony" only three years before the declaration of the U.S. "unipolar moment." 45

\section{Indicators of power}

This section develops indicators for the different approaches to power mentioned above. Of course, no indicator is perfect, nor can it encapsulate every aspect of a concept of power. Though power has sometimes been treated as the "currency of international politics," ${ }^{16}$ power is less fungible than money. ${ }^{47}$ That is, military power may not be particularly useful for achieving normative or economic goals. Also different from currency, many concepts of power are not easily quantifiable-or even observable or attributable. Quantification has been on attraction for resource-based approaches, but may offer at most a glimpse at the "base" of more relational and social forms.

\section{Military power}

Traditionally, power in the international arena was synonymous with military capabilities. A number of prominent IR scholars still hold this view, notably offensive realist John Mearsheimer. "Great powers are

\footnotetext{
41 Peter Bachrach and Morton S Baratz, "Two Faces of Power," AMERICAN POLITICAL SCIENCE REVIEW 56, no. 04 (1962).

42 Steven Lukes, Power: A Radical View, vol. 1 (London Macmillan, 1974).

${ }^{43}$ Susan Strange, "The Persistent Myth of Lost Hegemony," International Organization 41, no. 04 (1987).

${ }^{44}$ Michael Barnett and Raymond Duvall, "Power in International Politics," International Organization 59, no. 01 (2005): p. 42.

${ }^{45}$ Charles Krauthammer, "The Unipolar Moment," Foreign Affairs 70, no. 1 (1990).

46 This phrase is often used by John Mearsheimer.

${ }^{47}$ David A Baldwin, "Power Analysis and World Politics: New Trends Versus Old Tendencies," World Politics 31 , no. 02 (1979): p. 174.
} 
determined largely on the basis of their military capability. To qualify as a great power, a state must have sufficient military assets to put up a serious fight against in an all-out conventional war against the most powerful state in the world." 48 Mearsheimer's view, while influential, is an extreme position in IR theory today. However, even many non-realist scholars recognize the central role of military capabilities in world politics. Joseph Nye has compared international power today to "a complex three-dimensional chess game." Military power, dominated by the United States, is the top board; multipolar economic power sits in the middle; the diffuse realm of transnational relations sits at the bottom, with a multitude of states and non-state actor exercising power. ${ }^{49}$

In the Western Hemisphere, to a far greater extent than in the world as a whole, the United States retains its overwhelming military advantage. In 2014, U.S. spending accounted for about a third of total world military spending. While this is below the heights of the late 2000s, it is nearly the same as the U.S. portion of military spending in $1990 .^{50}$ Chinese military spending has climbed steadily, but its capabilities are not focused on power projection beyond its immediate geographical surroundings. Military power is, perhaps, the domain of international politics most germane to a relative power analysis. While far from perfect, military spending is the clearest indicator of a state's military capabilities. In this measure, the United States remains unrivalled in a global setting, despite a decline to a three-to-one advantage relative to China. Despite the famed inefficiencies and overpayment of the U.S. Department of Defense, the imbalance in military spending likely understates the U.S. advantage in capabilities. U.S. military power builds on decades of high spending, providing advantages in accumulated kit, training, and experience.

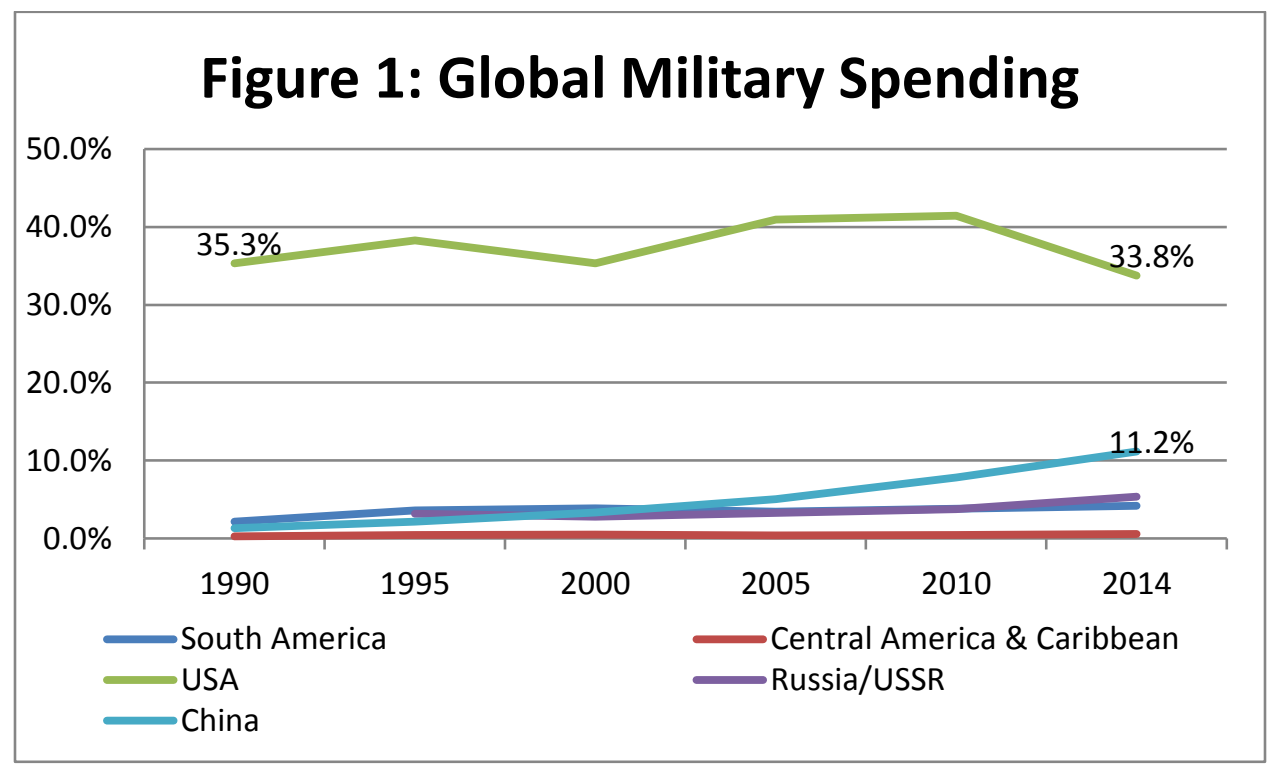

Source: Calculations by author; data from SIPRI Military Expenditure Database

\footnotetext{
48 John J. Mearsheimer, The Tragedy of Great Power Politics (New York: Norton, 2001), p. 5.

49 Joseph S Nye, "The Future of American Power," Foreign Affairs 89, no. 6 (2010).

${ }^{50}$ U.S. spending was $35.3 \%$ of world spending in 1990 and $33.8 \%$ in 2014 . Calculations by the author, using data from the SIPRI Military Expenditure Database, Stockholm International Peace Research Institute (SIPRI), accessed 24 March 2016. http://www.sipri.org/research/armaments/milex/milex database
} 
This rough measure also understates the U.S. power advantage vis-à-vis extra-hemispheric actors in the Americas. The question of decline implies a temporal comparison, either of absolute U.S. power as compared to other states. Despite highly publicized visits from Russian ships to Cuba and Venezuela, no extra-hemispheric power has a meaningful military presence in the hemisphere. On the other hand, the United States has recently increased the prominence and headquarters budgets of the U.S. Southern Command, the division of joint military forces that oversees the South American "area of responsibility.

\section{Figure 2: Southern Command HQ Budget}

\section{Combatant Command Mission and Headquarters-Support Costs ${ }^{b}$}

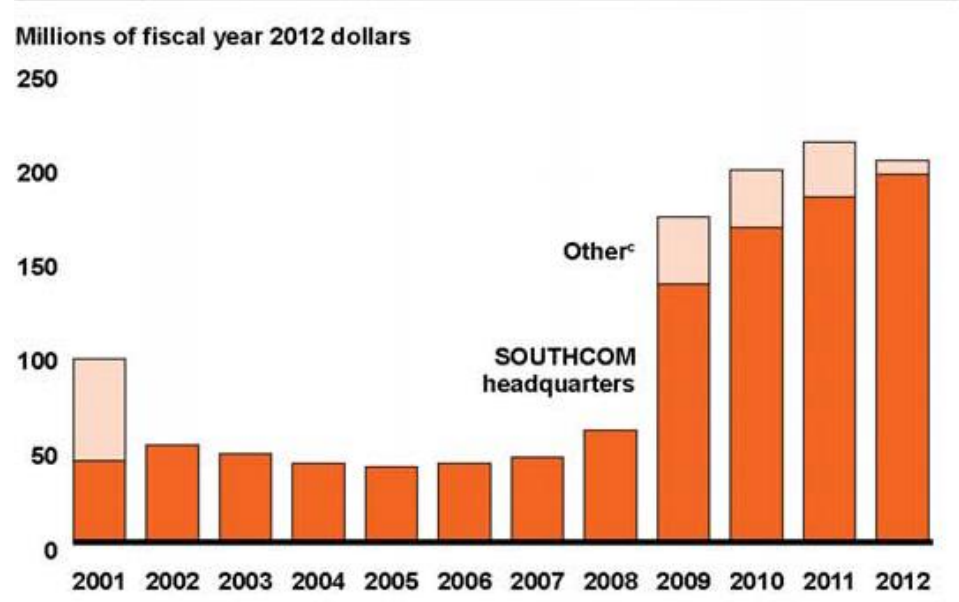

Source: U.S. GAO (2013). "Defense headquarters : DOD needs to periodically review and improve visibility of combatant commands' resources : report to Congressional committees."

Relative to states in Latin America, the preeminence of U.S. military spending has also experienced a decline-though from a state of exaggerated asymmetry to only somewhat less extreme asymmetry. At the same time, the disparity is similar to the levels from 1995-2000, when U.S. dominance was rarely questioned. The United States spends seven times the total spending of Latin America and the Caribbean. Recent increases (some of it with U.S. assistance, as in Colombia and Mexico) do not cut into the U.S. advantage. According to Mearsheimer's militarily based definition, no state in Latin America can be considered a great power. None is even trying. 


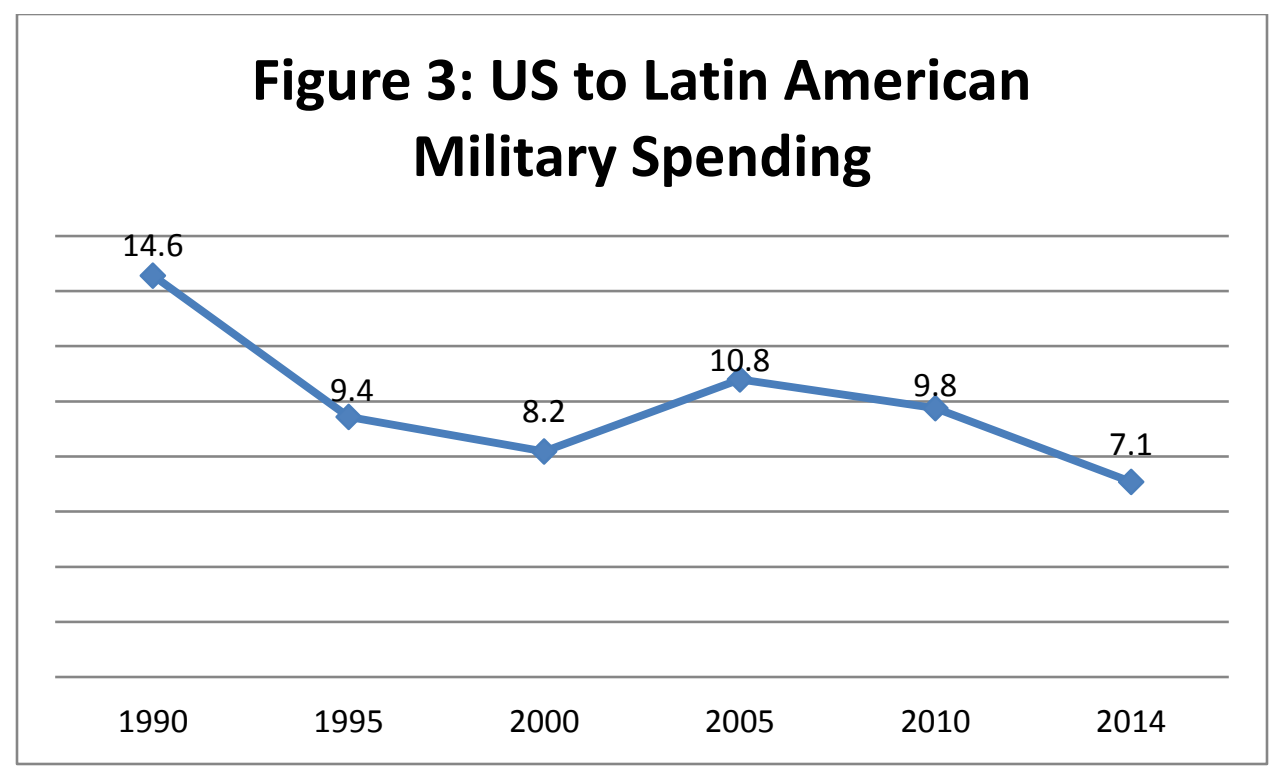

Source: Calculations by author; data from SIPRI Military Expenditure Database

Due to the global nature of the U.S. military presence, these figures roughly describe the military power Washington could bring to bear, but offer little about how it has positioned its military power.

Interestingly, despite (or perhaps because) Latin America was seen in the Cold War as the U.S. zone of military influence, the U.S. presence there has long been relatively light. It became even lighter during the late Cold War and fell further in the 1990s. One analyst decried "declining US [military] influence and increasingly divergent US-Latin America military interests" as far back as $1993 .{ }^{51}$

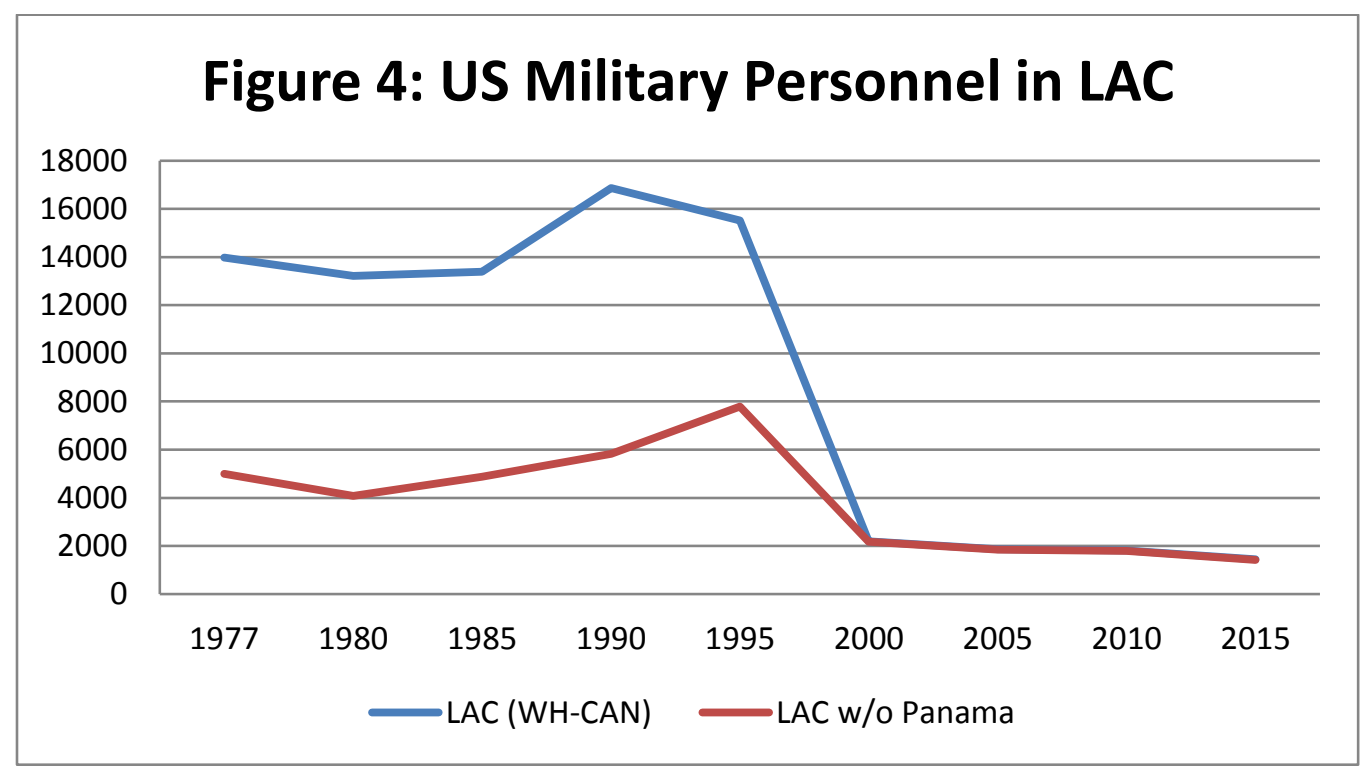

Source: US DoD Defense Manpower Data Center

\footnotetext{
51 John Samuel Fitch, "The Decline of U.S. Military Influence on Latin America," Journal of inter-American studies and world affairs 35, no. 2. For Fitch, the hey-day of U.S. military influence was during the 1950s and 1960s.
} 
As Figure 4 shows, the United States has not stationed significant forces in Latin America and the Caribbean since the mid-1990s. The decline in U.S. military presence happened largely as a result of the closure of U.S. bases in the Panama Canal Zone. By 2000, there were only 20 U.S. military personnel left in Panama. The U.S. presence at Guantanamo Bay, Cuba, had been decreased dramatically to 688, following a surge related to the Haitian migration crisis of the mid-1990s. The 1990s was a decade of decreasing foreign troop presence across most of the world-the so-called "peace dividend." For both questions of U.S. priorities and for global shifts in deployed personnel (which could represent changed technology or strategy), it is important to contextualize U.S. deployments in Latin America.

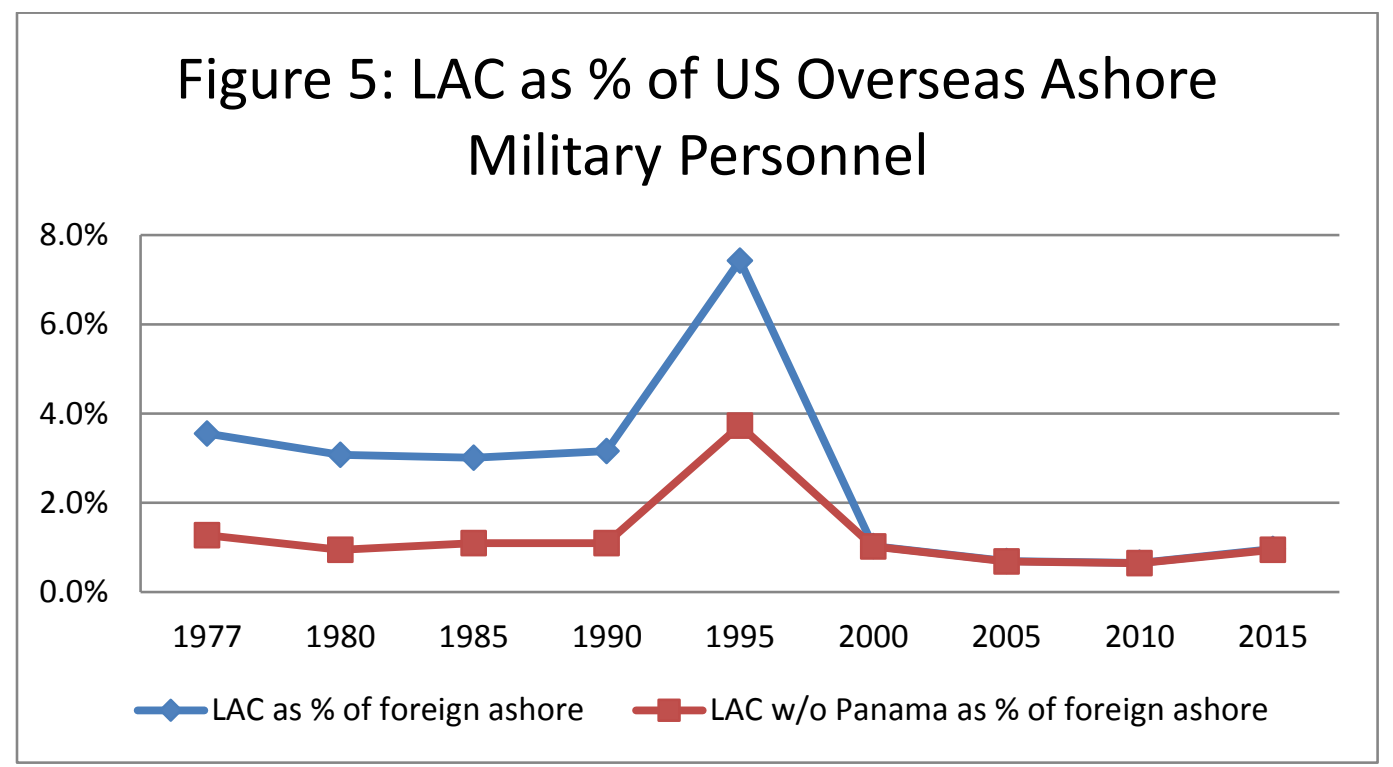

Source: US DoD Defense Manpower Data Center

As in Figure 5, Latin America has never been a major area for U.S. troops stationed abroad. The spike in 1995 represents increases in Haiti and Guantanamo Bay, linked with the U.S. deployment to Haiti and the migration crisis. ${ }^{52}$ The relatively low portions of total deployment-never reaching 8 percent-may reflect the U.S. ability to project power from the Southern United States to the Caribbean Basin. That ability has not declined. The declines in U.S. military presence in Latin America occurred two decades ago, as the U.S. military shifted its force structure away from Panama. This final point raises one last metric of supposed U.S. decline in the hemisphere: the rejection of U.S. military bases. On this point, the U.S. presence has always been light compared to deployments to Europe, Asia, and the Middle East, with the exception of the Second World War. According to extensive research by David Vine, at the end of the Cold War, the U.S. military maintained bases in Honduras, the Canal Zone, and Guantanamo Bay, along with naval facilities in the Bahamas and Antigua and Barbuda. There was a small base in Argentina. ${ }^{53}$ Today, the U.S. presence in the Caribbean is lighter, but despite high-profiled opposition to the U.S. base in Ecuador, the Pentagon has been able to maintain its force projection capabilities

\footnotetext{
${ }^{52}$ Calculations by the author, data from US DoD Defense Manpower Data Center. Online: https://www.dmdc.osd.mil/appj/dwp/dwp_reports.jsp ${ }^{53}$ David Vine, Base Nation: How US Military Bases Abroad Harm America and the World (Metropolitan Books, 2015).
} 
through lower-profiled agreements and "lily pads" that arouse less domestic opposition. It is worth noting that the expansion of U.S. presence was sought by Colombian leadership under Uribe until it was rejected by the courts; likewise, the role of U.S. military and DEA agents has grown in Mexico and Central America. ${ }^{54}$

According to various indicators of military power, U.S. dominance both globally and especially in the hemisphere has not experienced a precipitous decline, if it can be seen as having declined at all. Sabatini and others have argued that military power is the least effective U.S. tool in achieving influence in Latin America. ${ }^{55}$ That might risk a short memory-it has not been so long since the United States deployed troops to the region. In the historical context of U.S.-Latin American relations, the military imbalance was a significant component of asymmetry, dating from the U.S.-Mexican War to the days of the Roosevelt Corollary through the overt and covert interventions of the Cold War, up to interventions in Panama and Haiti in the 1990s. The military can be an effective base of power through security cooperation, military aid, weapons sales, training, humanitarian aid, and more. These are all relevant to inter-American relations today.

\section{Economic power}

The relationship between economics and power is nothing new in International Relations, though many scholars have argued that the salience of explicitly economic forms of exercising power have grown in importance since the late Cold War period. Economic power can be assessed in various ways, either through possession of wealth as a resources convertible to other forms of power or through economic relationships such as trade and investment. These are examined below.

\section{Economic power: Wealth}

Realist and Liberal scholars have long agreed that wealth - the size and composition of a state's economy - is a fundamental base of power. ${ }^{56}$ This view has also been central to arguments that the United States is in a nearly inevitable phase of relative decline, based on projections of future Chinese (or decades earlier, Japanese) economic growth, with the assumption that economic size will translate to power, however defined. ${ }^{57}$ There is, of course, no question that global concentrations of wealth have grown increasingly diffuse during the last decade. To some extent, this continues a long-term decline from the U.S. preponderance emerging from the Second World War. The first wave of this diffusion occurred with the rebuilding of Europe and Japan; this was followed by a second wave of Soviet industrialization and European economic growth. More recently, from 1995 to 2014, China's share of global product increased a stunning $5 \frac{1}{2}$ times. The U.S. share stood at 23.8 percent of world product in 2014, a modest decline from its 25 percent share in 1995. Relative to China (despite emerging concerns about the reliability of Chinese economic statistics), however, the U.S. has seen a clear decline from

\footnotetext{
${ }^{54}$ Sebastian E Bitar, US Military Bases, Quasi-Bases, and Domestic Politics in Latin America (Palgrave Macmillan, 2015).

${ }^{55}$ Sabatini, "Will Latin America Miss US Hegemony?."

${ }^{56}$ Hans J. Morgenthau and Kenneth W. Thompson, Politics among Nations : The Struggle for Power and Peace (New York: Knopf : Distributed by Random House, 1985).

${ }^{57}$ Kupchan, No One's World: The West, the Rising Rest, and the Coming Global Turn, Paul Kennedy, The Rise and Fall of the Great Powers (Vintage, 2010).
} 
having a GDP more than 10 times as large as China's to just 1.7 times as large. This pathway toward parity is precisely what has fueled Realist concerns about the management of power transitions.

\section{Figure 6: Share of World Product}
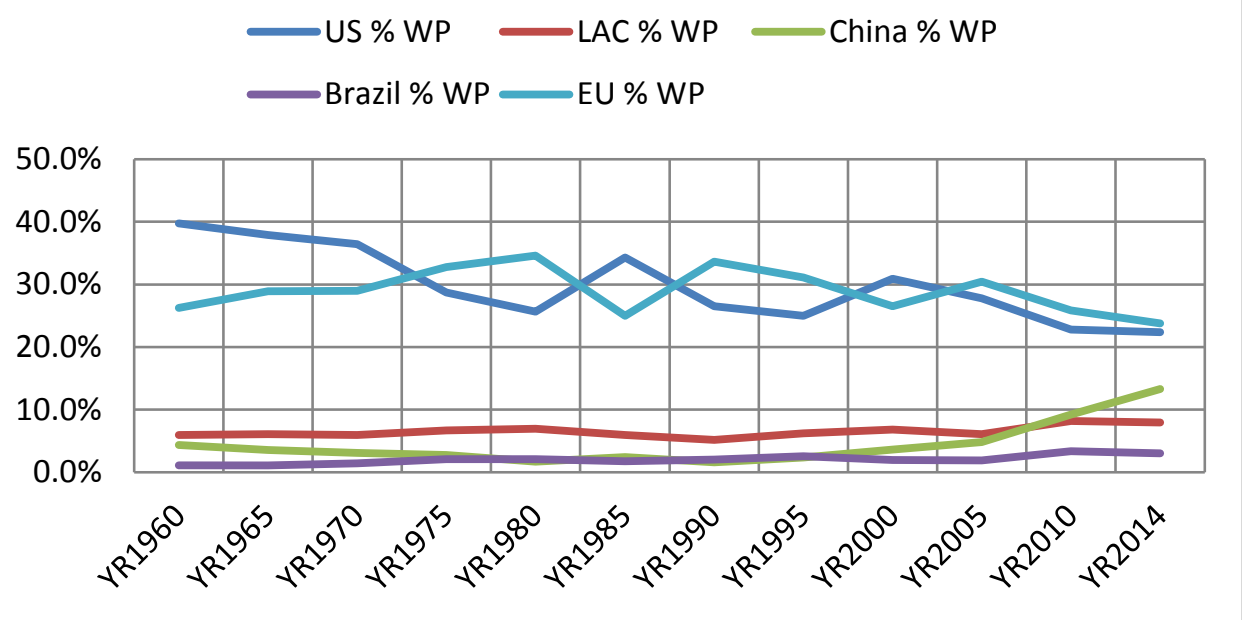

Source: Calculations and graph by author using data from World Development Indicators

However, this view treats Latin America as a space for great games-style external power competition-a sort of empty space for contestation. It replays Cold War concerns about U.S.-Soviet competition in the hemisphere, regardless of the reality, clear in hindsight, that much of this competition was overblown, that the Soviet presence beyond Cuba was limited, that local leaders exploited Washington's fears for their own gain, and that U.S. reactions to perceived Communist intrusions too often led to wrongheaded policies and support for brutal authoritarians. Beyond learning from that past, there are additional reasons why Chinese economic engagement in the Western Hemisphere is even less likely to function as a zero-sum game. Unlike with the Soviet Union during much of the Cold War, China and the United States are major, if not always harmonious, economic partners. This relationship extends to trade, investment, supply chains, location of corporate subsidiaries, purchases of public and private debt, etc. When China imports commodities from Latin America, it does so in part to fuel the factories and feed the workforces that produce goods for U.S. companies and U.S. consumers.

The "autonomy" perspective asks whether Latin America has enhanced its own economic power vis-àvis the United States. Here, again, the evidence is perhaps not as clear as previous economic and political projections have indicated. There has been a shift, but the doubts about its sustainability have become increasingly pronounced during the last several years as Latin America's leading economies have fallen into turmoil. As indicated in Figure 7, Latin America and the Caribbean, if taken as one unit, has reduced the overall disparity in GDP with the United States-though the reduction also reflects higher rates of population growth. The disparity in per capita income remains stubbornly wide. Disconcertingly for the region, with much of the region experiencing stagnant of negative growth (particularly in Brazil) the trend appears similar to previous, but ultimately temporary, reduction in 
disparity during the mid- to late-1970s. Similar factors drove some of that reduction-a commodities boom, slow U.S. growth, and a supply of cheap U.S. dollars on easy credit.

\section{Figure 7: US to LAC GDP Multiplier}

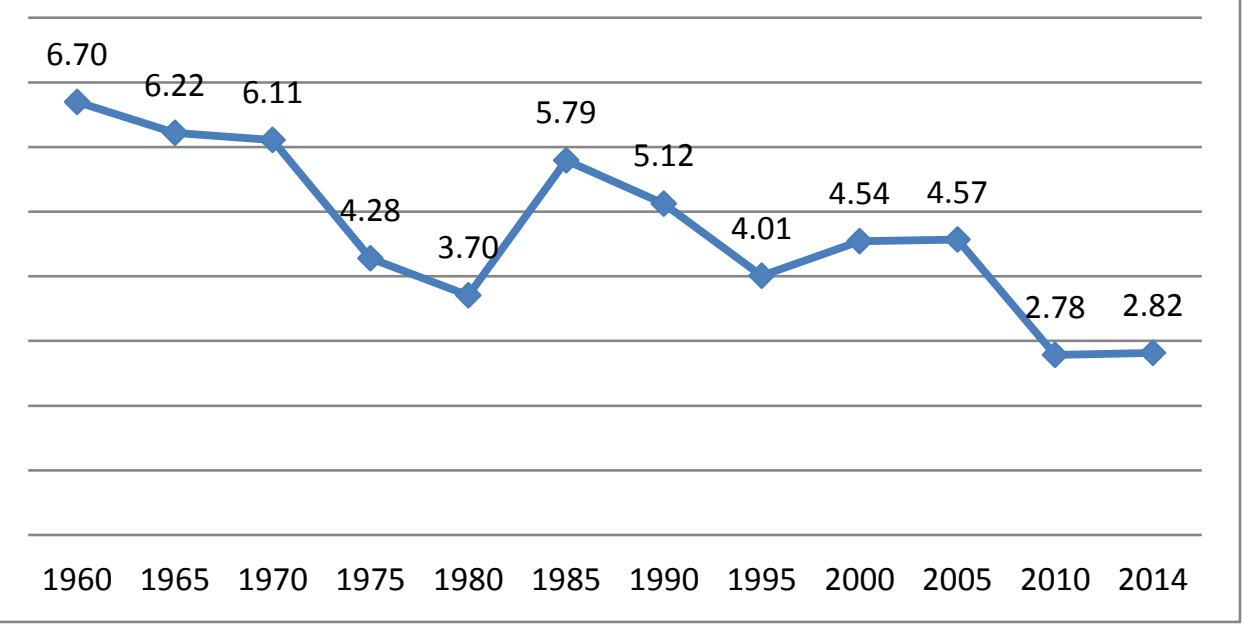

In brute terms, the gap is not as wide as it once was, but the reduction appears to have slowed and even reversed as Brazil's recession has deepened just as the United States has returned to stable, if unspectacular GDP growth. Over the longer term, the reduced disparities in total GDP disguise a continuation of the gap in per capita income, given higher population growth in Latin America during much of the period (Figure 8).

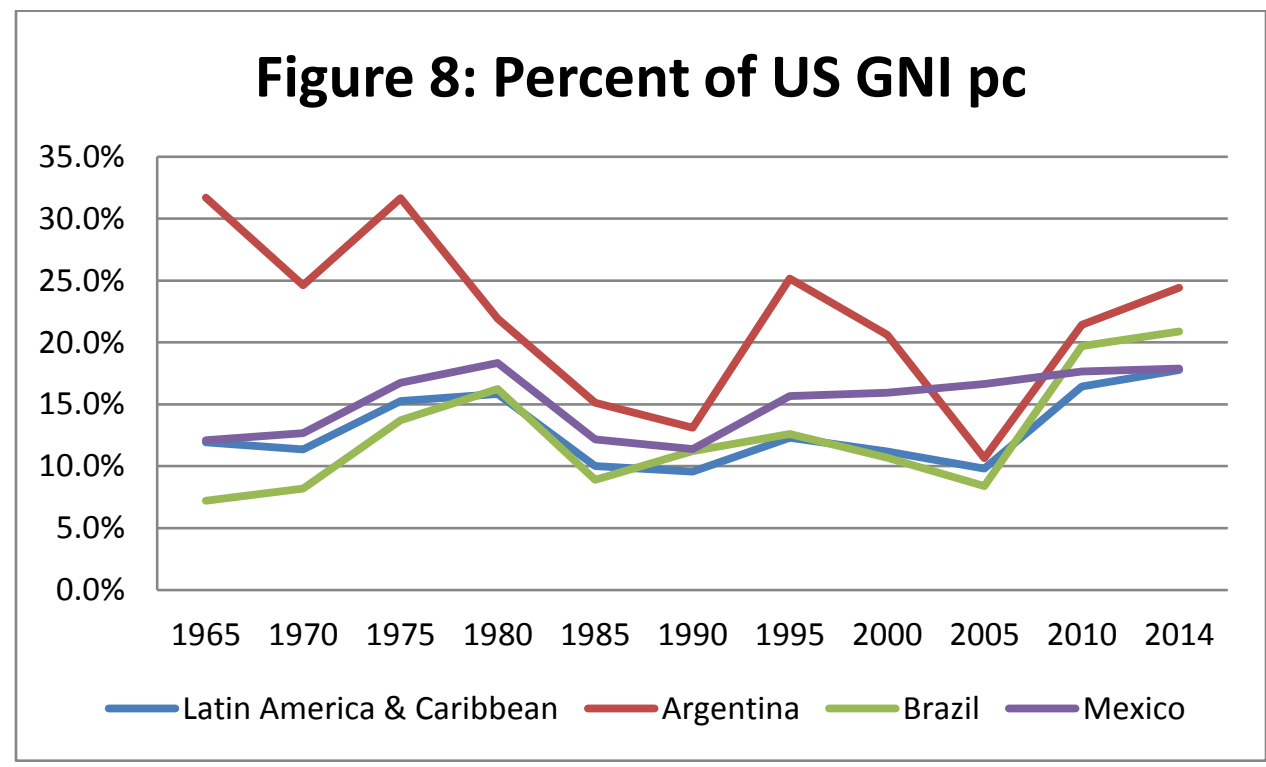

\section{Economic power: Trade}

Much of the recent South American economic rise was driven by high commodity prices, caused in part by an apparently insatiable Chinese appetite for primary goods. China has closed its GDP gap with the United States even more dramatically. In doing so, it has increased its economic presence in Latin 
America, moving from a marginal player 25 years ago to its current role as a central trade and investment partner. In the narrative propagated by many journalists and analysts until last year, this was a "win-win." A CNN economic analyst's version of the argument reflects this conventional wisdom: "It's a win-win for China and Latin America for many reasons. China needs all of Latin America's abundant commodities, like oil and soybeans, while some Latin countries are desperate for cash, which China is happy to provide." ${ }^{58}$ The narrative reflects stated Chinese policy that Latin American and the Chinese economies are essentially complementary-China manufactures and Latin America produces commodities $^{59}$-though this is precisely the relationship that Latin American economic policymakers long sought to escape.

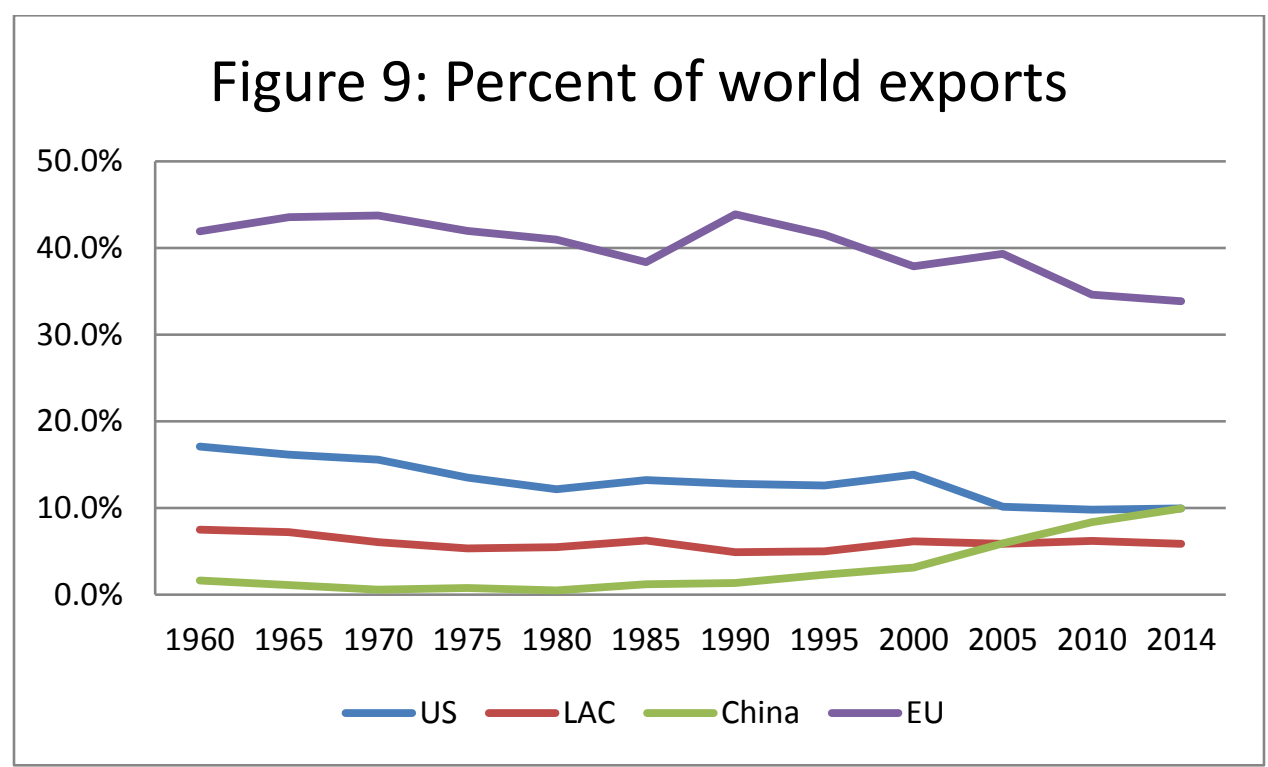

\footnotetext{
${ }^{58}$ Patrick Gillespie, "China's big chess game against the U.S. in Latin America," CNN Online, March 4, 2015.

${ }^{59}$ William Ratliff, "In Search of a Balanced Relationship: China, Latin America, and the United States," Asian Politics \& Policy 1 , no. 1 (2009): p. 7.
} 


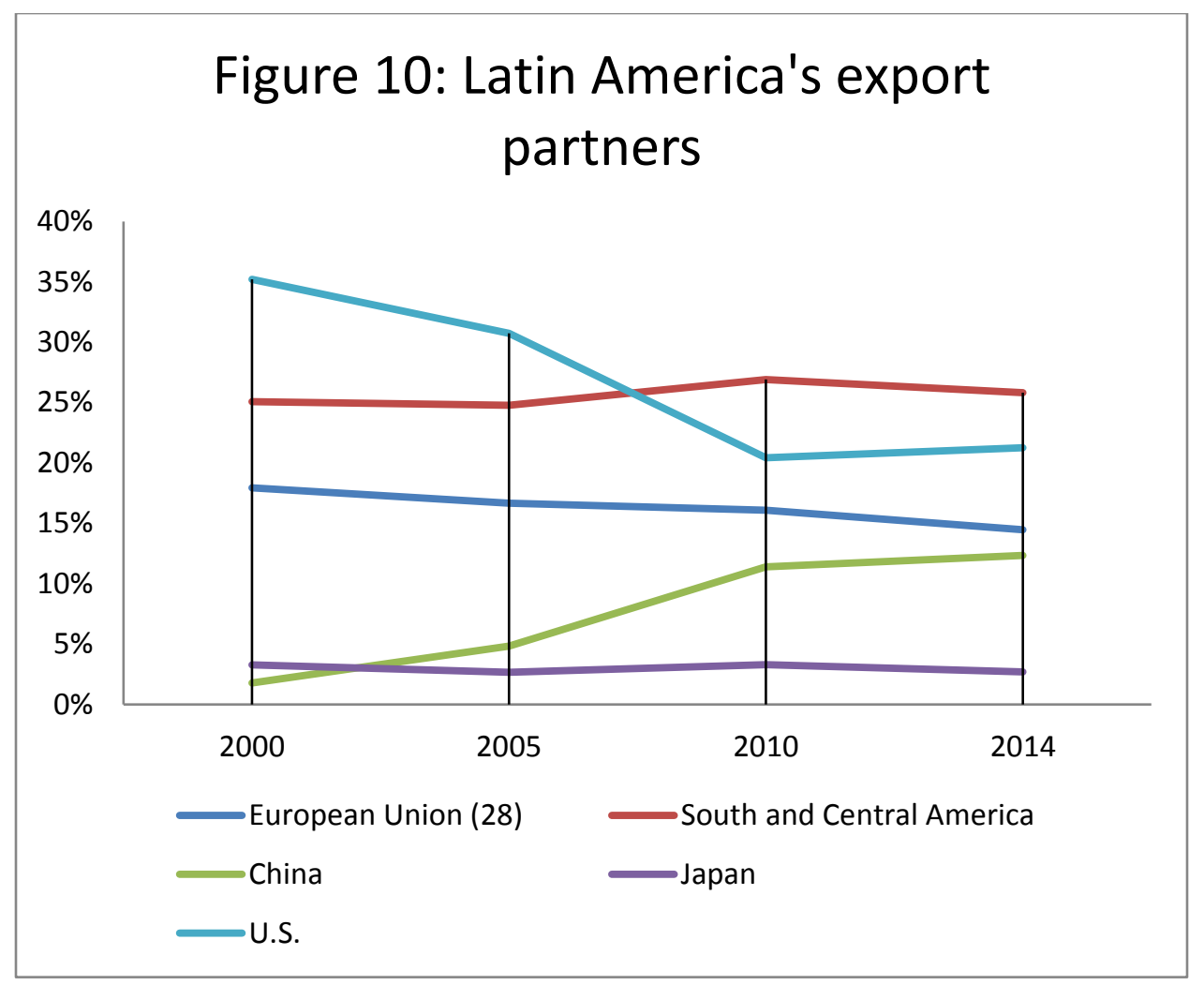

Source: Calculations and graphs by author using data from World Development Indicators

However, despite this growing global and regional role, there are reasons to question whether China's increased economic presence in Latin America should be seen as a "threat" to U.S. interests, or even as necessarily eroding U.S. power and influence. These reasons were present before the recent, sharp declines in commodity prices and Chinese growth rates, and are exacerbated by them. ${ }^{60}$ All but three countries in the region, Brazil, Argentina, and Bolivia, run trade deficits with China. In this sense, most of the Sino-Latin America relationship is similar to that of the United States and China, though on a smaller scale. Latin Americans are net importers of low-cost Chinese manufacturing, which to some extent displaces their own industrial goods from the U.S., world, regional, and domestic markets. ${ }^{61}$ The latest and most comprehensive studies on the subject question the long-term benefits of this relationship for Latin American economies-even for the three countries that had been net exporters. Much of Latin America has faced a degree of deindustrialization during the peak years of the China boom. ${ }^{62}$ A survey of changes in the Brazilian economy is illustrative.

${ }^{60}$ A number of analysts noted this with concern years ago. Nicola Phillips, "Coping with China," in Which Way Latin America? : Hemispheric Politics Meets Globalization, ed. Andrew Fenton Cooper and Jorge Heine (New York: United Nations University Press, 2009).

${ }^{61}$ Kevin Gallagher and Roberto Porzecanski, The Dragon in the Room: China and the Future of Latin American Industrialization (Stanford, Calif.: Stanford University Press, 2010).

${ }^{62}$ Kevin P Gallagher, The China Triangle: Latin America's China Boom and the Fate of the Washington Consensus (Oxford University Press, 2015). 


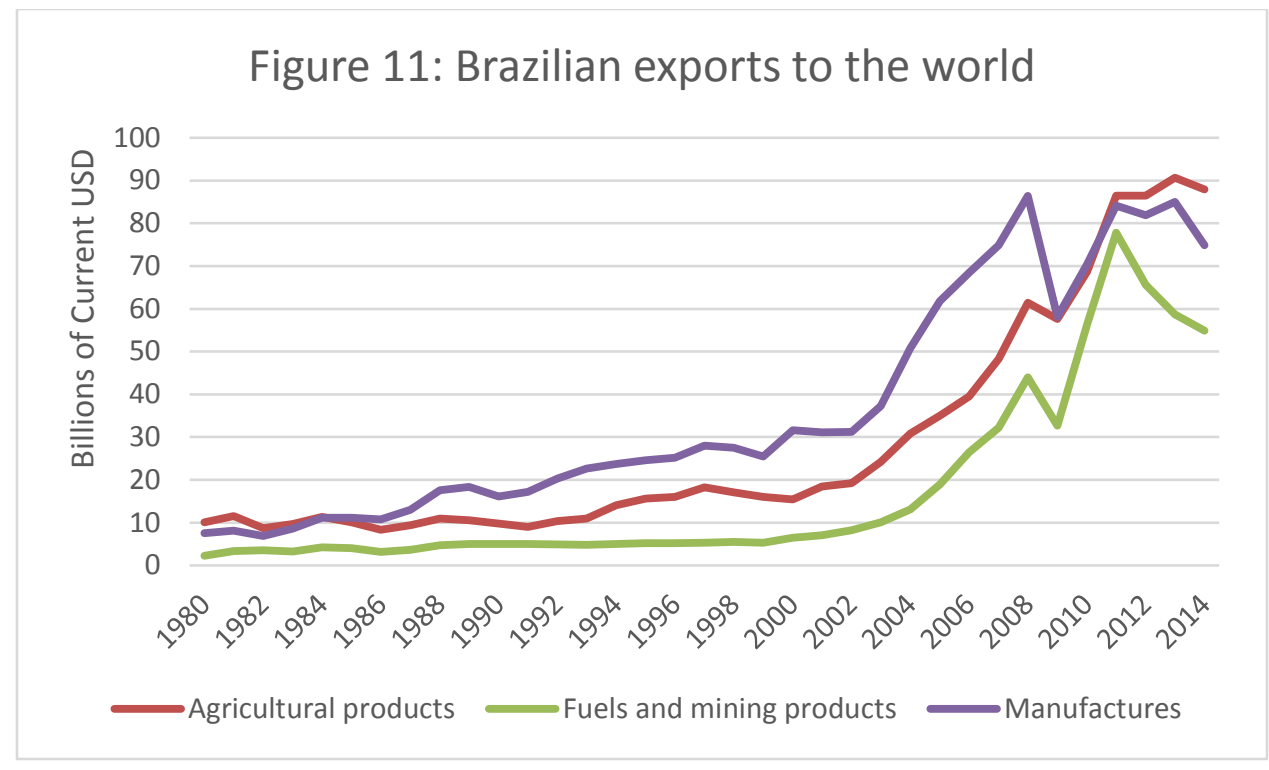

\section{Figure 12: Total Brazilian exports by type}

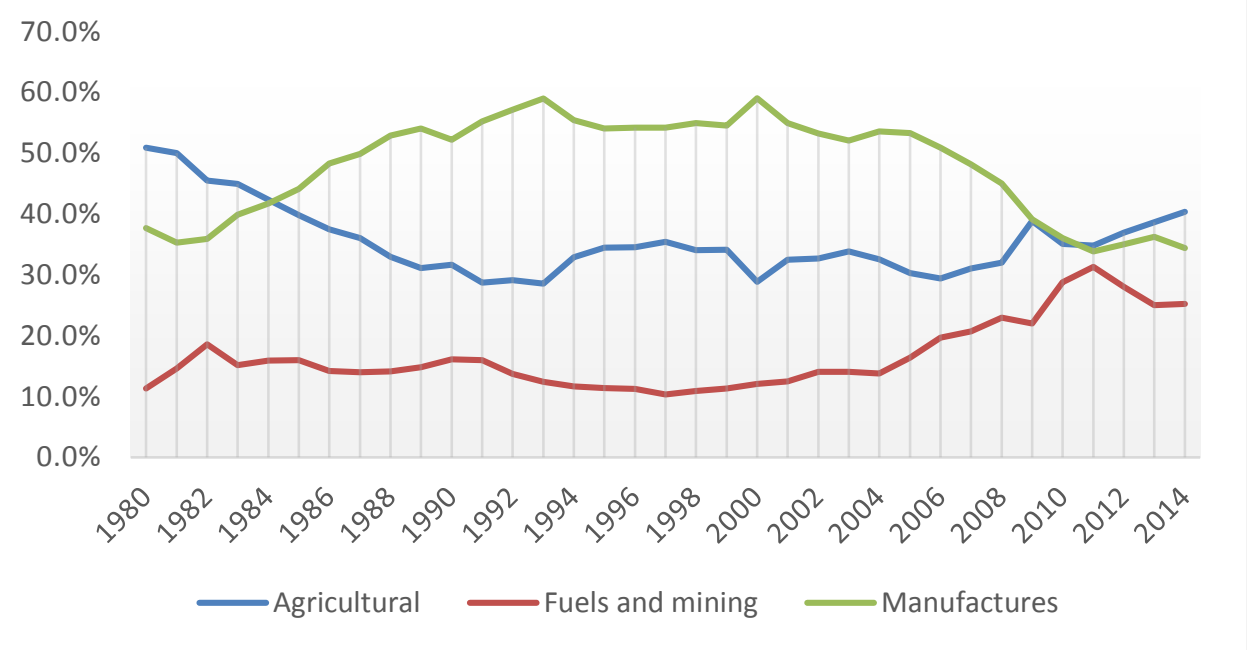

Brazil's exports of all types boomed from 2000-2011, when they began decelerating well before the ongoing political and economic crisis. However, as Figure 12 shows, during the boom, Brazil shifted from being an industrial powerhouse to being much more reliant on fuels, mining, and agricultural commodities. From a high of nearly 60 percent, manufacturing exports have fallen to just over a third of total Brazilian exports. ${ }^{63}$ Primary goods exports face much sharper price swings, while generally creating less value added in the form of backwards supply chains. The reorientation to China under the centerleft Workers Party (PT) reversed the longstanding pro-industrialization policies of Brazilian governments of many ideological stripes prevalent since the 1930s. Chinese prominence might reduce the U.S. role vis-à-vis an external power, even while it reduced present and future Brazilian autonomy in foreign

${ }^{63}$ Calculations and graphs by author using data from World Bank DataBank. 
economic policy. This is not just a Brazilian problem. A recent report notes that "the Latin American export commodity price index shows a fall of 30\% from its 2014 level." ${ }^{64}$

\section{Economic power: Finance and investment}

U.S. economic power in Latin American and the Caribbean has long been linked not just to the role of the United States' huge market as a trading partner but as the major source of public and private loans and direct investment. The relationship with U.S. capital has long been ambivalent; Latin American leaders have often eagerly sought FDI and loans on the New York capital markets while also expressing reservations about the power exercised by U.S. companies and the U.S. government through "dollar diplomacy." Often, those who argue that U.S. power in the region has diminished cite related developments that enhanced Latin American fiscal autonomy from the United States. On the one hand, budget surpluses and growing reserves diminished Latin American reliance on U.S. capital, as well as on U.S.-headquartered international financial institutions like the IMF, World Bank, and Inter-American Development Bank. This fiscal flexibility came from economic growth and, especially, high commodity exports. On the other, Latin American economies now had new sources of both investment and finance - especially from China. Chinese finance seems to continue expanding, even as traditional IFI sources have retrenched. ${ }^{65}$ Much of this has come via loans, estimated to have reached \$29 billion in 2015. While this financing is significant, and surpassed IFI funding for 2015 , it is also highly concentrated. A stunning 95 percent of funding from China's development and export banks went to just three countries: Brazil, Ecuador, and Venezuela. The loans are also concentrated on production of raw materials and the construction of infrastructure to bring those materials to the Chinese market. ${ }^{66}$ While the press often either hails or disparages Chinese lending and investment as "no strings attached, that is not quite right. First, dealings with China have long been presaged on non-recognition of Taiwan. Beyond that, the loans are often backed with claims to natural resource production and sometimes require the purchase of Chinese equipment (similar to U.S. Export-Import Bank loans). China has announced the creation of new, designated funds for infrastructure lending in the region, though the missions and capitalization of these funds is not entirely clear in the context of both Chinese and Latin American economic slowdowns. The concentration of this finance in raw materials and its lack of transparency raise concerns about its long-term implications for receiving countries' development models. ${ }^{67}$

Shifts in Chinese commercial lending and FDI are more difficult to document, in part because this funding is often routed through offshore financial havens, including Hong Kong, the Netherlands, Luxembourg, and Caribbean states, and in part because some Latin American governments do not keep

\footnotetext{
${ }^{64}$ Economic Commission for Latin America and the Caribbean (ECLAC), "Economic and Social Panorama of the Community of Latin American and Caribbean States, 2015," (Santiago, Chile: United Nations, 2016).

${ }^{65}$ Kevin P. Gallagher, "Latin America Needs a Plan to China's Latin America Plan," in Latin America Goes Global, Latin America Goes Global (Washington, D.C.: 2016).

${ }^{66}$ Kevin P. Gallagher and Margaret Myers, "China-Latin America Finance Database," (Washington, D.C.: InterAmerican Dialogue, 2016).

${ }^{67}$ Margaret Myers, Kevin P. Gallagher, and Fei Yuan, "Chinese Finance to LAC in 2015: Doubling Down," in ChinaLatin America Report (Washington, D.C.: Inter-American Dialogue, 2016), Margaret Myers, "Shaping Chinese Engagement in Latin America," in Routledge Handbook of Latin America in the World, ed. Jorge I. Domínguez and Ana Covarrubias Velasco (New York: Routledge, 2015).
} 
statistics on FDI. Fully 92 percent of Chinese FDI in Latin America and the Caribbean went to two states: the British Virgin Islands and the Cayman Islands. Some of this likely ended up in Latin America, but figuring out how much requires significant estimation. ${ }^{68}$ At least in official statistics, ECLAC notes that "This leads to a significant underestimation of China's role in FDI in Latin America and the Caribbean."69 Figures 13 and 14 show FDI flows into Mexico and Brazil, and Chinese investment barely registers. The While official statistics might underestimate, the popular narrative likely overstates. Many high-profiled Chinese investments and loans are announced, but do not come to fruition; official statistics are rarely published as a corrective. There is no doubt that, globally, Chinese FDI has increased rapidly since the early 2000s. A 2013 CEPAL report estimated \$10 billion per year in Chinese FDI since 2010, driven largely by big acquisitions in oil in Argentina, Brazil, and Venezuela, and in mining in Peru. ${ }^{70}$

\footnotetext{
${ }^{68}$ Economic Commission for Latin America and the Caribbean, "Chinese Foreign Direct Investment in Latin America and the Caribbean," (Santiago, Chile: United Nations, 2013).

${ }^{69}$ Economic Commission for Latin America and the Caribbean, "Foreign Direct Investment in Latin America and the Caribbean, 2015," (Santiago, : United Nations, 2015), p. 30.

${ }^{70}$ Caribbean, "Chinese Foreign Direct Investment in Latin America and the Caribbean."
} 


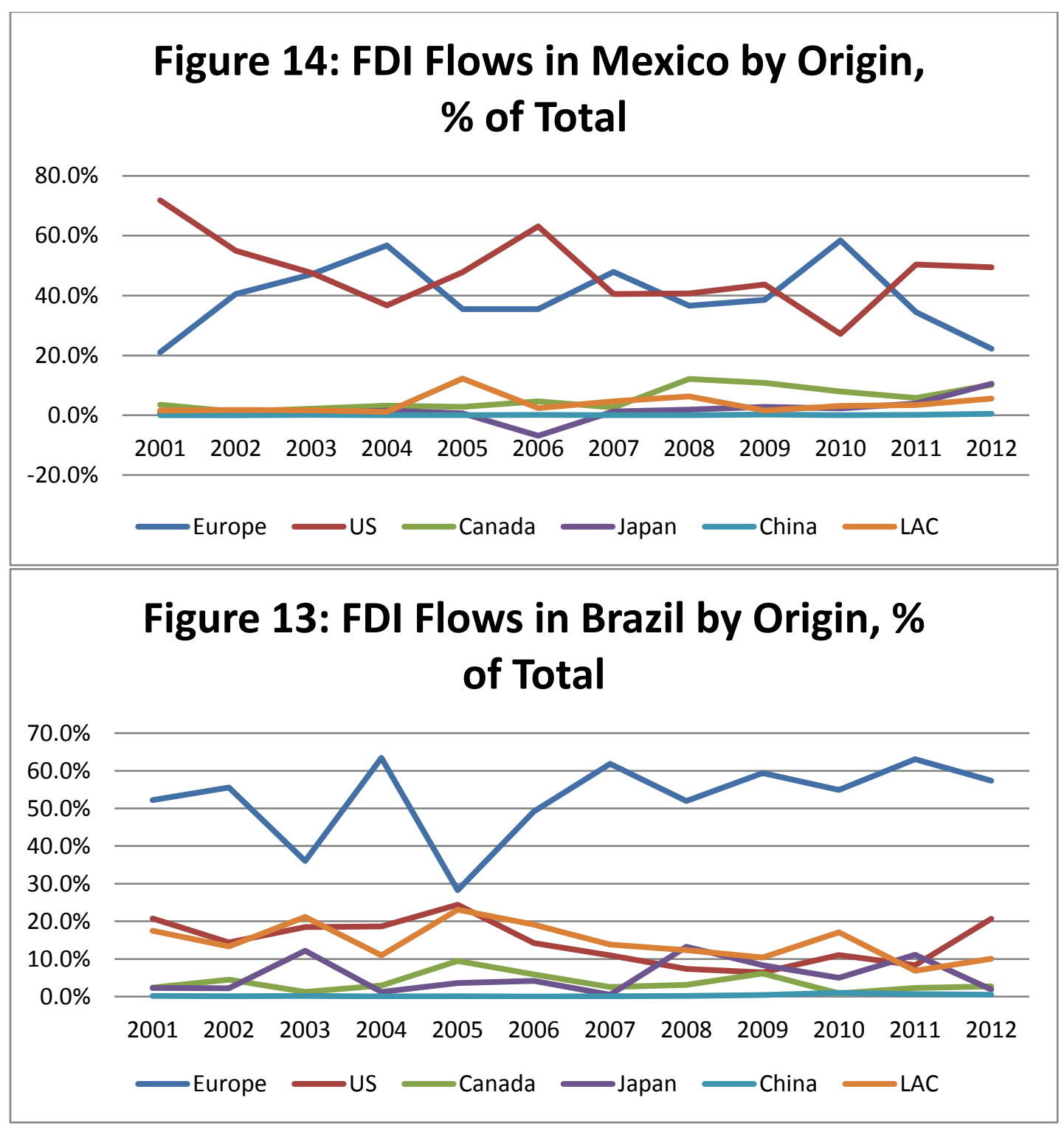

Source: UNCTAD Bilateral FDI Statistics, 2014

Recent currency trends have likely improving the position of U.S. companies, as all Latin American currencies and the euro have slid against the dollar. "Meanwhile, mergers and acquisitions, which are generally denoted in dollars, have become more expensive for European investors, but cheaper for investors from the United States." Where Europe has been the major FDI partner, U.S. purchases have not offset European declines. ${ }^{71}$ U.S. and European companies dominate investment in the services sector, including in the banking and financial industry.

In 2015, all countries in the region ran fiscal deficits despite widespread public spending cuts, a major turnaround for a region that had often ran surpluses since 2009. ECLAC notes that the region is

${ }^{71}$ Caribbean, "Foreign Direct Investment in Latin America and the Caribbean, 2015," p. 20. 
vulnerable to increases in interest rates, ${ }^{72}$ a s the burden of dollar-denominated debt has increased given shrinking export earnings and major drops in local currencies against the dollar. Much of this debt appears to be held in the corporate sector, but just how much is not clear. ${ }^{73}$

Regardless of its effects, several South American governments have clearly seen Chinese finance as a way to diminish reliance on Washington and avoid mounting fiscal pressures. Many of these same countries have seen their government credit status harshly downgraded, so access to capital markets will be difficult and more costly. U.S. financial power has likely experienced a relative decline vis-à-vis China. However, in both stock and flow terms, the power of U.S. and European finance and multinational corporations remains unparalleled. Even based on bullish, unofficial estimates, CELAC noted, "In other words, China's economic influence over Latin America is conducted mostly through trade and not through direct investment." ${ }^{74}$ Unlike Chinese capital, U.S. investments are widely diversified both in terms of geography and economic sector-including playing an important role in Latin America's own financial sector. Additionally, even much Chinese-issued commercial debt appears to be through dollar-based bond offers, a reflection of lasting U.S. structural power in the region, discussed below.

\section{Structural power}

While structures are important for a number of IR theories, ${ }^{75}$ the term structural power is most closely associated with the work of Susan Strange. In 1987, she argued that "structural power decides outcomes (positive and negative) much more than relational power does, and the United States' structural power has, on balance, increased." Here, it is meant in Strange's sense, as the ability to shape structures within which states and people must operate. Strange locates these in security, production, finance, and knowledge. For at least three (with perhaps a partial exception for production), it seems that U.S. structural power within the hemisphere remains as dominant as in 1987. Even in production (like with finance), the "rules of the game" are set by the United States directly or through institutions it heavily shaped and continues to influence. These form the rules of the game in the global economy and grant the United States subtle, but consistent, advantages. ${ }^{76}$ One such structure is the role of the U.S. dollar as the de facto currency of most international trade. This role allows the United States to impose sanctions, punish violators in its own courts, finance its large trade and fiscal deficits, and "ease" its money supply with comparatively few consequences. Despite steps to "internationalize" the Chinese RMB, nearly all trade outside the Euro zone is conducted in dollars; dollars also still amount to a heavy majority of international reserves. ${ }^{77}$ While arguments on U.S. decline often point to the 2008-2009 financial crisis as

\footnotetext{
72 (ECLAC), "Economic and Social Panorama of the Community of Latin American and Caribbean States, 2015," p. 16.

${ }^{73}$ Economic Commission for Latin America and the Caribbean (ECLAC), "Capital Flows to Latin America and the Caribbean: Recent Developments," (Santiago, Chile: United Nations, 2015), p. 12.

${ }^{74}$ Caribbean, "Chinese Foreign Direct Investment in Latin America and the Caribbean," p. 12.

75 Emerson, "Radical Neglect? The "War on Terror" and Latin America," pp. 34-37, Alexander E. Wendt, "The AgentStructure Problem in International Relations Theory," International Organization 41 (1987).

76 Strange, "The Persistent Myth of Lost Hegemony."

${ }^{77}$ Marc Auboin, "Use of Currencies in International Trade: Any Changes in the Picture?," (World Trade Organization (WTO), Economic Research and Statistics Division, 2012).
} 
a turning point, the United States actually seems to have emerged from with a stronger hold on its international currency position. ${ }^{78}$

While China has become a crucial source of finance for some countries in Latin America, these same countries have seen themselves more heavily affected by the decisions of the U.S. Federal Reserve than by Chinese development banks. Similarly, there have been several moves toward "currency independence" in Latin America, promoted by Mercosur and other regional organizations. However, many of these deals were negotiated during a period of strong, and stable, currency prices for major Latin American economies. That stability has eroded. The value of the dollar has come roaring back against the Brazilian real and the Mexican and Colombian pesos. Figure 15 shows fluctuations in the values of those three currencies against the U.S. dollar, with their 1994 values indexed to 100 for comparison (higher values here represent weaker local currencies).

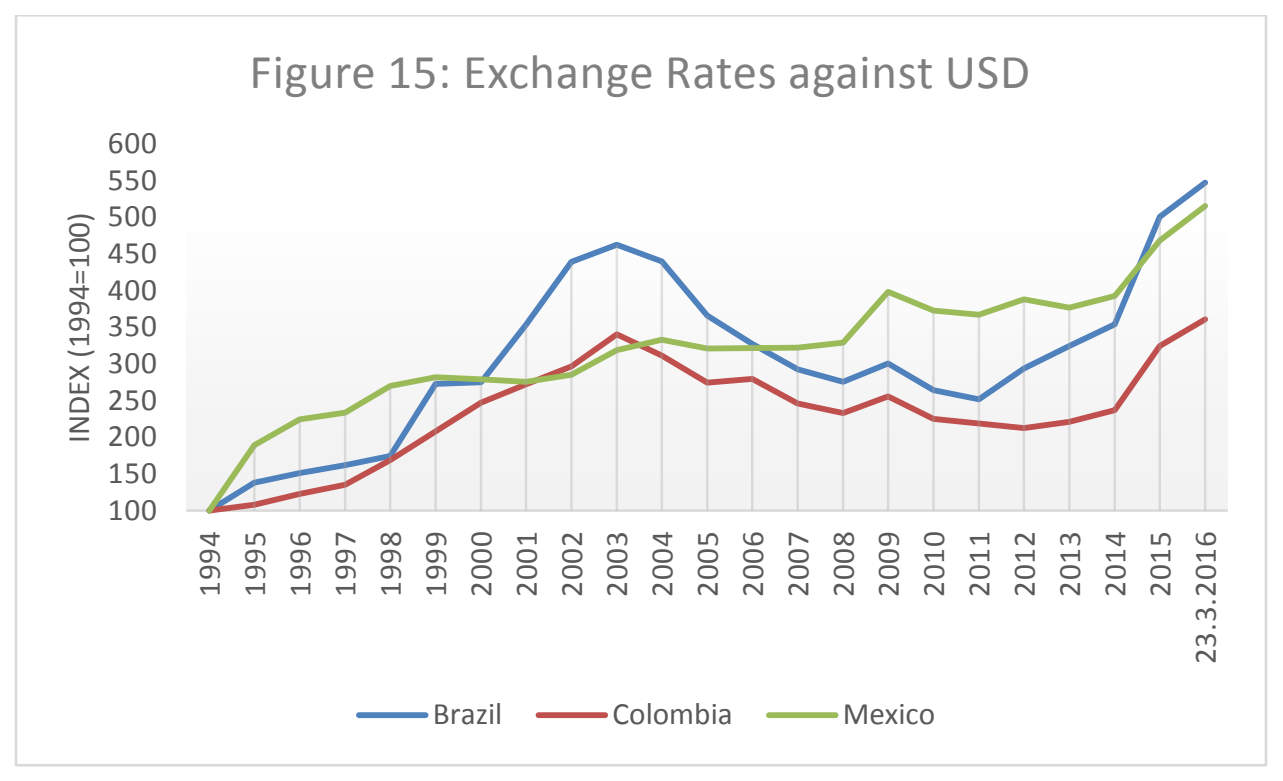

Source: Calculations by author based on exchange rate data from OECD Annual Average Exchange Rate; 2016 rate from Google Currency.

This alone does not prove the structural role of the dollar (the Swiss franc would also have strong rates against these currencies), but given the prominence of dollars as both a personal, private bank, and governmental store of value in these countries, the fluctuations have real effects. Mexico, for example, spent heavily to defend the peso over the last two years (2015-2016), with limited success in halting its decline. Brazilian aspirations that the real increasingly would be used as a currency of exchange and reserve in South America have been brought low by the country's political and economic crises, and the resultant volatility in the real's value. Dollar-denominated borrowing skyrocketed in Brazil, surpassing $\$ 300$ million in 2014, much of it issued as offshore bonds and debt securities. In Bolivia, Peru, and

\footnotetext{
78 Benjamin J Cohen and Tabitha M Benney, "What Does the International Currency System Really Look Like?," Review of International Political Economy 21, no. 5 (2014), Eswar S Prasad, The Dollar Trap: How the US Dollar Tightened Its Grip on Global Finance (Princeton University Press, 2015).
} 
Mexico, dollar-based loans account for a fifth to a third of the total domestic market. ${ }^{79}$ Even as Brazilian rhetoric and symbolic policies emphasized a move away from the hegemony of the U.S. dollar, the country's own economic trends told a different story.

\section{Relational power}

If power, most fundamentally, is about changing behavior, then the ultimate question is whether the U.S. ability to change Latin American states' actions has diminished. The query is deceptively simple. It implies a counterfactual: absent U.S. power, the Latin American state would have acted differently. It is also, ultimately, case specific and very difficult to meaningfully aggregate. The most effective approach to studying the question is through case studies that involve close process-tracing, which seeks to untangle competing causes and explanations. ${ }^{80}$ In lieu of that, if is worth examining some of the key episodes held up as illustrating declining U.S. ability to change behavior. Williams' chapter in a new, prominent Handbook of Latin America in the World offers a striking example. In it, he concludes that, "By the end of the $21^{\text {st }}$ century's first decade, Latin American governments had stopped paying much attention to the United States." Williams demonstrates this through, "Multiple indices [that] reflect the remarkable decline of U.S. regional influence.

“These include Washington's failure to

- win much regional backing for its military operations against Iraq (just five small client states joined the military crusade),

- coax Chile and Mexico to support U.S. war plans against Iraq in the UN Security Council, - induce regional powers to accept the 2002 coup that briefly deposed Venezuelan president Hugo Chávez,

- persuade Paraguay and Peru to join the United States in a military alliance against Venezuela, - convince its neighbors to support U.S. initiatives in the OAS,

- sway key regional powers to formalize the FTAA, and

- maintain decidedly warm bilateral relations with as many as a half dozen Latin American governments." 81

These were, indeed, striking events where the United States failed to achieve its ideal policy outcome, falling back to a Plan B or further. However, there are historical parallels to each of them in periods now presumed to be zeniths of U.S. influence. For example, one might highlight how Washington:

- Failed to win the backing of a single Latin American state for its invasion of Panama (1989-1990), which was conducted without UNSC or OAS approval, ${ }^{82}$

\footnotetext{
${ }^{79}$ Robert N McCauley, Patrick McGuire, and Vladyslav Sushko, "Global Dollar Credit: Links to US Monetary Policy and Leverage," Economic Policy 30, no. 82 (2015).

80 This is the reverse attempted, in reverse, in Long, Latin America Confronts the United States: Asymmetry and Influence.

${ }^{81}$ Williams, "The United States and Latin America."

${ }^{82}$ Bruce W. Watson and Peter Tsouras, Operation Just Cause : The U.S. Intervention in Panama (Boulder: Westview Press, 1990).
} 
- Was forced to use a UNSC veto (just its third ever) to reject a Latin America-backed UNSC resolution on the Panama Canal in 1973, ${ }^{83}$

- Struggled, then made major concessions, in order to obtain a resolution in the wake of the CIAbacked coup against Jaboco Arbenz in 1954, ${ }^{84}$

- Failed to persuade Mexico, Costa Rica, and other states to back attacks against the Sandinista government in Nicaragua or leftists in El Salvador- instead facing counter-plans in the 1980s, ${ }^{85}$

- Faced opposition to U.S. trade efforts from regimes that favored import substitution policies during the 1970s; or conversely, faced and eventually accepted the nationalization of U.S. oil assets in Mexico in the 1930s.

These counterexamples do not constitute a definitive rejection of Williams' cases (better would be to examine each in depth, but there is not adequate space in this article or documentation available for many of the cases to do so). However, they call attention to the concerns of selection and saliency biases, and to the risks of overstating U.S. omnipotence in the past.

\section{Conclusions}

In a critical essay on the vast range of work assuming a "Western" decline, Michael Cox noted, "that this modern story, exciting and interesting though it is, tends to focus almost entirely on what is rapidly changing but says little about what is not - and what is changing much less than some are now suggesting is America's position in the world. ${ }^{186}$ Cox's warning applies to analyses of the U.S. position in Latin America. Too much of the argument about the United States' decreased stature in the hemisphere is based on anecdotal evidence and the zeitgeist of the George W. Bush administration. In this sense, it is important to recall that Latin American states have long exhibited signs of policy autonomy. Extrahemispheric powers have long been major investors and trade partners for much of Latin Americaespecially Europe for the Southern Cone. The United States has been previously beset by political crises that hampered its ability to conduct effective relations with Latin America and the world-such as Watergate and Vietnam. Finally, Latin American states have, for decades, vociferously opposed certain U.S. actions. These developments are not as new as they seem, even as they adopted new forms in the mid-2000s. This is not to conclude that nothing has changed, but instead to emphasize the importance of remembering the continuities. Partial influence, policy friction, and Latin American efforts to appeal to institutions, international law, and extrahemispheric actors to increase their autonomy are not so new. ${ }^{87}$ However, they take place in a context of unequal power relations; that context has not

\footnotetext{
${ }^{83}$ Tom Long, "Putting the Canal on the Map: Panamanian Agenda-Setting and the 1973 Security Council Meetings," Diplomatic History 38, no. 2 (2014).

${ }^{84}$ Max Paul Friedman, "Fracas in Caracas : Latin American Diplomatic Resistance to United States Intervention in Guatemala in 1954," Diplomacy \& Statecraft 21, no. 4 (2010).

${ }^{85}$ Mario Ojeda, Retrospección de Contadora: los Esfuerzos de México para la Paz en Centroamérica (1983-1985) (Mexico: El Colegio de Mexico AC, 2007).

${ }^{86}$ Cox, "Power Shifts, Economic Change and the Decline of the West?," p. 372.

${ }^{87}$ Max Paul Friedman and Tom Long, "Soft Balancing in the Americas: Latin American Opposition to U.S. Intervention, 1898-1936," International Security 40, no. 1 (2015).
} 
disappeared. A century of asymmetry is not erased in a decade, especially when the material and social bases of this asymmetry remain strong. 